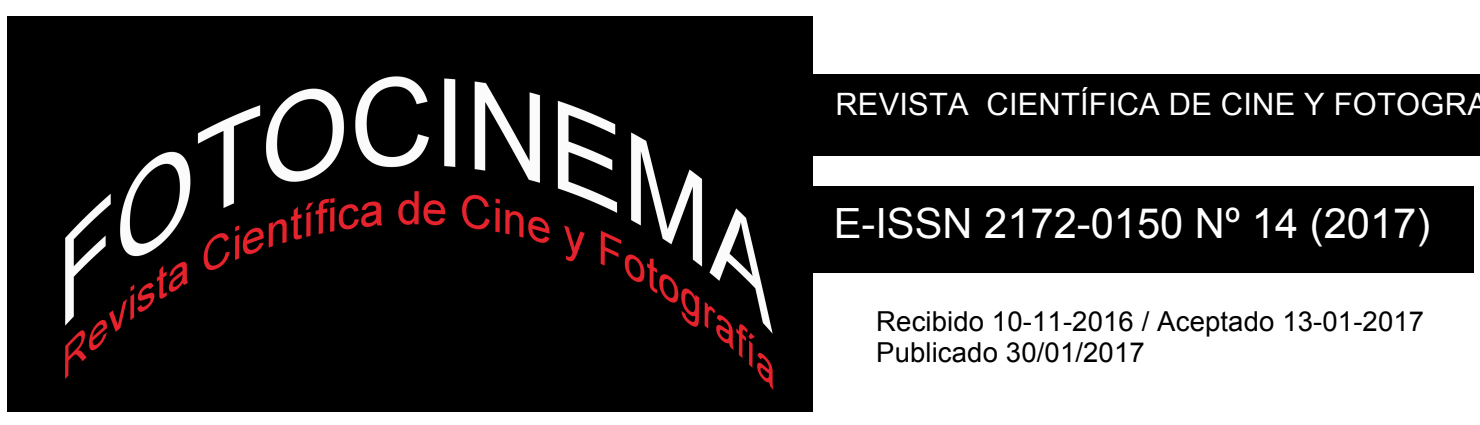

\title{
EL CINE DE JORGE SEMPRÚN. LA TRANSFERENCIA ENTRE GUIONES CINEMATOGRÁFICOS, LITERATURA Y BIOGRAFÍA
}

\author{
JORGE SEMPRÚN'S CINEMA. TRANSFER BETWEEN \\ SCREENPLAYS, LITERATURE AND BIOGRAPHY
}

Ricardo Jimeno Aranda Universidad Complutense de Madrid, España rijimeno@ucm.es

\section{Resumen:}

Jorge Semprún es una de las figuras más destacadas dentro de la cultura española y europea del siglo XX, debido a su carácter poliédrico como político, intelectual, escritor; $y$ cineasta. Es precisamente esta última faceta, en relación con su trayectoria en los otros campos, la que menos interés ha suscitado dentro de los abundantes estudios y biografías surgidos en torno a su figura. El artículo se propone indagar en su obra cinematográfica como guionista, y también como director de un único filme documental, pero partiendo de la perspectiva de la relación directa de influencia e inspiración en múltiples direcciones entre sus creaciones para el cine, las obras de terceros autores en que ocasionalmente se basan sus libretos, y su propia creación literaria, todo ello imbuido siempre de su rica experiencia biográfica, paralela a algunos de los principales acontecimientos históricos del siglo $\mathrm{XX}$, y filtrada por un elaborado estilo creativo basado en los mecanismos de la memoria, a caballo entre realidad y fabulación.

\begin{abstract}
:
Jorge Semprún is one of the most outstanding figures in the Spanish and European culture of the 20th century, due to his polyhedral character as a politician, intellectual, writer, and filmmaker. It is precisely this last facet, in relation to its trajectory in the other fields, that less interest has aroused in the abundant studies and biographies that have arisen around its figure. The article intends to investigate in his cinematographic work as scriptwriter, and also as director of a single documentary film, but starting from the perspective of the direct relation of influence and inspiration in multiple directions between his creations for the cinema, the works of third authors in which his screenplays are occasionally based, and his own literary creation, always imbued with his rich biographical experience, parallel to some of the major historical events of the twentieth century, and filtered by an elaborate creative style based on the mechanisms of memory, riding between reality and fable.
\end{abstract}

Palabras clave: cine; cine político; guión; literatura; memoria; política

Keywords: Cinema; Political Cinema; Screenwriting; Literature; Memory; Politics 


\section{Introducción}

\subsection{Semprún polifacético}

La trayectoria vital y creativa del español Jorge Semprún (Madrid, 1923París, 2011) plantea uno de los modelos más polifacéticos que pueden encontrarse en el entorno europeo, y particularmente en el español a lo largo del siglo XX. Su recorrido biográfico, que podría dividirse en dos grandes etapas - la de la acción entre 1936 y 1963; y la de la creación entre el 63 y el año de su muerte; con el paréntesis de su etapa como ministro de Cultura en el gobierno de Felipe González (1988-1991)-, prácticamente describe el arco histórico europeo entre la lucha antifascista, la Guerra Civil Española, la Segunda Guerra Mundial, la Guerra Fría y el proyecto de construcción europeo. En su primera etapa como activista político, Semprún, descendiente de dos familias de la alta burguesía española, nieto del presidente Antonio Maura, e hijo de un diplomático republicano, se exilió junto con su familia al comienzo de la Guerra Civil, luchó en la Resistencia Francesa, fue internado en un campo de concentración nazi y posteriormente luchó clandestinamente como miembro del Partido Comunista de España contra la dictadura de Franco, hasta su expulsión del partido en 1964, por sus diferencias ideológicas con Santiago Carrillo y Pasionaria. En su segunda etapa -la de la creación- integrado en la aristocracia cultural francesa, Semprún se convirtió en un escritor de éxito a partir de la publicación de su primera novela, El largo viaje (1963), alternando las novelas de ficción y los denominados ensayos biográficos, que a menudo (por no decir categóricamente siempre) giraban en torno a las obsesiones, vivencias y traumas de su primera etapa como activista. Pero además, Semprún se convirtió en un guionista de cine cotizado trabajando a las órdenes de algunos de los más reputados cineastas europeos contemporáneos como Costa-Gavras, Alain Resnais o Joseph Losey, e incluso convirtiéndose, aunque sea un detalle anecdótico, en el primer español en ser nominado al Oscar en la categoría de guión. Su trabajo cinematográfico incluye también la dirección de un filme documental muy personal Las dos memorias (Les deux mémoires, 1974), muy poco visto hasta la fecha, objeto de una restauración 
reciente. Con la instauración de la democracia en España, Semprún se convierte en un referente político e intelectual, siendo llamado al gobierno por Felipe González en 1988, cargo del que dimite en 1991. Semprún muere en el año 2011 en París, después de dos décadas de actividad literaria ininterrumpida.

\subsection{Entre la vida, el cine y la literatura. Objeto del artículo}

La intención de nuestro texto reside en plantear un análisis de las relaciones entre la trayectoria biográfica, la literaria y la cinematográfica de Semprún, estableciendo la perspectiva a partir de sus trabajos cinematográficos, esencialmente guiones, aunque sin olvidar el caso de su realización documental Las dos memorias.

En este sentido, la primera justificación del trabajo viene dada por un hecho diferencial todavía insólito, que tiene que ver con la consideración como creador de la figura de Semprún en nuestro país, notablemente relegada con respecto a la que ostenta en Francia e incluso en Alemania. Si bien, y especialmente a partir de su fallecimiento en 2011, parece existir un impulso por la recuperación de su figura, y ahí están dos obras biográficas de notable impacto editorial como las de Felipe Nieto y Soledad Fox Maura, lo cierto es que incluso en ellas, y quizá de forma comprensible por primar el aspecto histórico-político de su personalidad, la labor como cineasta (guionista y director) de Jorge Semprún queda absolutamente relegada a lo anecdótico. Existe en ellas -especialmente en el caso de la obra de Soledad Fox- un intento por relacionar su creación literaria con la biográfica, analizando y comparando pasajes, pero en ningún caso se introduce ahí la raíz cinematográfica. Son pocos los textos que se dedican al Semprún cineasta, e incluso alguno de ellos, como el excelente monográfico de la revista CinémAction coordinado por Jaime Céspedes, permanecen inéditos en nuestro país, aunque este último autor ha publicado recientemente un estudio en castellano sobre la obra cinematográfica y teatral sempruniana: La obra de Jorge Semprún. Claves de interpretación. Vol. II: Cine y teatro (2015). 
La segunda justificación vendría dada por la original relación que se establece entre los trabajos fílmicos de Semprún, su producción literaria, la producción literaria de otros autores y su propia biografía personal. Es decir, raramente tiene lugar en la creación sempruniana y en esas relaciones cinematográfico-literarias un sentido o dirección única que permita hablar de adaptaciones puras. Muy al contrario, la querencia creadora de Semprún gira en torno al concepto variable de memoria, entendida según sus propias palabras como un recurso inagotable "que se expande y se dilata en el espesor del tiempo acumulado" (Semprún, 1998, p. 187).

Esa idea de memoria que se transforma al expresarse es la que permite que toda la obra sempruniana (cinematográfica y literaria) se despliegue como un tejido bordado a partir de diferentes teselas y piezas, constituyéndose a partir de reflexiones filosóficas y políticas, que permiten incluso la repetición de determinados temas y recuerdos en obras diferentes con nuevas aproximaciones, como si se produjese una reflexión de la reflexión en nuevos contextos, o una variación jazzística. De ahí, el interés de tratar de analizar ese universo sempruniano (político, creativo, vital) desde el enfoque menos habitual de su trabajo para el cine.

\section{Metodología}

El planteamiento del análisis, a tenor de lo expuesto en la introducción, ha partido, por tanto, de precisar las relaciones entre la creación literaria y los aspectos biográficos de los principales filmes en los que Jorge Semprún ha participado como guionista, $\mathrm{y}$, por tanto, autor - habida cuenta además de la evidente impronta personal que se halla de forma expresa en ellos-, así como en el único filme dirigido por él.

En función del enfoque, el método empleado ha sido el planteamiento de un análisis comparativo, de signo principalmente historiográfico, de la trayectoria fílmica y literaria, completado por un breve estudio de caso, a partir de un análisis narrativo de las interrelaciones entre su cine y su literatura, a partir de algunos pasajes significativos de sus filmes más representativos, así como de los elementos biográficos consignados a partir 
de la abundante bibliografía - generada también por el propio Semprún en sus "ensayos biográficos"-, en función de la relación entre las fuentes ordenadas de un modo cronológico en base a la anterioridad o posterioridad de la obra cinematográfica con respecto a la literaria o viceversa. No obstante, cabe incidir aquí en la particularidad de que, si bien en ocasiones puede hablarse en puridad de adaptaciones, en otras ocasiones hemos de ceñirnos a la idea de versiones o variaciones sobre un mismo tema o episodio.

De esta manera, en un primer apartado se consignarán aquellos filmes escritos por Semprún sin atender a una base literaria, pero que recogiendo de modo elíptico pero expreso elementos biográficos, han sido filtrados posteriormente en diversos escritos del autor. En concreto el primer guión que escribe, La guerra ha terminado (La guerre est finie, Alain Resnais, 1966) y Las rutas del sur (Les routes du sud, Joseph Losey, 1978). Así mismo, hemos considerado pertinente incluir en este apartado su único filme, el documental Las dos memorias (1974). En un segundo gran apartado, nos encontraríamos con diversos guiones escritos por Semprún que parten de un texto literario ajeno, por tanto son expresamente adaptaciones de novelas, ensayos o textos previos, e incluso hechos históricos, pero en los que Semprún filtra de modo evidente rasgos de su biografía, a su vez contenidos en otras obras suyas anteriores o posteriores. Este es el caso de los tres títulos que Semprún co-escribió con el cineasta grecofrancés Costa-Gavras, que han ocupado la parte fundamental de nuestro análisis $-Z$ (id., 1969), La confesión (L'aveu, 1970) y Sección especial (Section spéciale, 1975)-, así como de otros dos filmes que contienen características similares en cuanto a la relación con otras creaciones literarias y experiencias semprunianas; en concreto Stavisky (id., Alain Resnais, 1974), basado en hechos históricos, y Una mujer en la ventana (Une femme à sa fenêtre, Pierre Granier-Deferre, 1976), adaptación de una novela. 


\section{De la vida al cine y del cine a la literatura}

Tras su éxito literario con El largo viaje en 1963, obra en la que narra por primera vez su experiencia de la deportación, que provee al escritor del prestigioso Premio Formentor y le otorga un estatus como prometedor novelista, Semprún termina de un modo más o menos lógico - a partir de su relación con un grupo de intelectuales parisinos, encabezados por el actor y simpatizante comunista Yves Montand- llamando la atención del cineasta Alain Resnais que le encarga el guión de La guerra ha terminado (1966), filme notorio en que Semprún aborda por primera vez la reflexión compleja sobre la Guerra Civil Española y el papel de la militancia antifranquista en el periodo. Semprún deposita en el filme -a través de un alter-ego metafórico llamado Diego Mora y encarnado, como ocurrirá en múltiples ocasiones, por su amigo Montand-, su andadura como militante clandestino del PCE bajo el pseudónimo de Federico Sánchez. La película conjuga temáticamente a partir de este planteamiento dos líneas generales. Por un lado, la de la acción -tanto política como emocional, convenientemente combinada a partir del sello de juegos temporales y espaciales propio tanto de Semprún como de Resnais- del personaje en su militancia clandestina en España y su doble vida identitaria en Francia; y, por otro, la de la reflexión, en este caso sobre su desencanto comunista y sobre su apreciación contraria a la línea seguida por el PCE clandestino en su oposición al régimen de Franco.

A partir de esta breve descripción, podemos encontrar en primer lugar que el motor creativo del texto del filme parte de un esquema en tres niveles que el autor introducía ya de modo primitivo en su primera novela El largo viaje, pero que particularmente repetirá en muchos de sus escritos. Estos tres niveles se corresponden con el Semprún creador, el Semprún militante real, es decir, Federico Sánchez, por recurrir a su alias más repetido y reconocible (aunque utilizara muchos otros a lo largo de su vida clandestina durante el nazismo o el franquismo), y el Semprún personaje de libro o de cine, muchas veces depositados en alter-egos que confunden a los dos primeros -el fabulador y el militante con pseudónimo-, conformando un tejido ficticio bruñido de (in)distinguibles elementos de su realidad biográfica. 
En La guerra ha terminado, el primer nivel lo constituiría el Semprún guionista del filme, que da cuenta en su creación del Semprún militante -es decir, de Federico Sánchez- filtrado a través del tercer nivel, esto es, el personaje de Diego Mora interpretado por Yves Montand. La particularidad es que las líneas temáticas del filme, en las que Semprún a través del personaje de Diego Mora da cuenta de modo retrospectivo y en presente de sus actividades como espía clandestino en la España franquista, y de sus reflexiones en presente sobre la inutilidad de la lucha, presiden también de forma primordial el contenido de uno de sus más celebrados (y polémicos) libros, Autobiografía de Federico Sánchez - el primero escrito en castellano, además-, publicado en 1977. En esta obra literaria, con el trasfondo de un evidente ajuste de cuentas con el PCE, focalizado en la figura de su secretario general Santiago Carrillo, Semprún vuelve a introducir los tres niveles de expresión que aluden en definitiva a sí mismo, el suyo como escritor, el de Federico Sánchez como referente real y el de Federico Sánchez como personaje de su escrito o autobiografía fabulada.

Pero incidiendo en la particular relación entre el filme y la obra literaria, hay entre ambos textos una línea común en la que, haciendo una analogía con los tres niveles, el Semprún creador filtra la misma realidad fabulada a través de un personaje, con la peculiaridad de que el filme antecede a la obra literaria. Es decir, pareciera que Semprún "adapta" y amplía a la literatura su creación cinematográfica. La ampliación es evidente en tanto que la novela se detiene en un recorrido mucho más proceloso y lleno de meandros en clave circular partiendo y culminando en el momento exacto en que la vida de Semprún en sus tres niveles- se transforma: la celebración del comité del PCE, presidido por La Pasionaria, en que Semprún y su compañero Fernando Claudín son expulsados del partido, pero en su sentido poético y en su contenido compartimentado, la Autobiografía de Federico Sánchez adapta a la literatura el film La guerra ha terminado, basándose ambos en la experiencia real fabulada del autor, incluso utilizando la misma fórmula de referirse al protagonista en una peculiar segunda persona del singular, como si entre el Semprún narrador y el Semprún personaje se estableciese una conversación. 
Por razón de espacio nos atendremos a comparar un pasaje que muestra la inspiración evidente entre ambos textos en clave de transferencia creativa, más allá de la fuente real que los nutre. La primera secuencia de La guerra ha terminado muestra un coche detenido en un puente en la frontera española. A bordo, de copiloto, Diego Mora (Yves Montand) conducido por un militante. El coche cruza el puente y la voz en off del personaje dice lo siguiente, mientras un plano subjetivo muestra el agua desde el puente: "Has pasado. Una vez más, miras la colina de Biriatou. Una vez más, tienes ese rancio e inquieto sabor al cruzar la frontera. Condujiste toda la noche. Tienes la boca seca, de dormir poco y del humo del tabaco. Una vez más, cruzas la frontera con la estremecedora luz de madrugada. El sol sale detrás de ti en torno a Elizondo. Una vez más, vas a cruzar" (Resnais, 1966). La acción prosigue y en la escena presente se intercalan, a modo de breves recuerdos (seña común del film y traslación fílmica de un recurso habitual en la literatura sempruniana) de sus encuentros con otros militantes variados en puertas de pisos, que se suceden fugazmente, paseos rápidos por Madrid, hasta que la acción vuelve en forma circular al paso de la frontera.

Atendamos ahora a un pasaje de la Autobiografía de Federico Sánchez, en el momento en que Semprún narra el final de su clandestinidad y la obtención de su pasaporte legal para entrar en España:

Sanseacabó la emoción de los pasos clandestinos, la alegría de antaño cada vez que franqueaba el viejo puente de Behobia para entrar en mi país sin permiso de nadie. Relumbraba el sol en las aguas del Bidasoa, o bien bajo un cielo encapotado, lluvioso acaso, se deslizaban lentamente las aguas grises del río fronterizo. Bueno, ya estaba. Una vez más había pasado esa línea invisible y radical. Una vez más volvía a los paisajes de mi infancia, a la terca y obstinada alegría del trabajo político clandestino, a la fraternidad de Madrid, con Nieves y Ricardo, con Javier y Gabriela, con Domingo y Carmela, con los compañeros todos. (Semprún, 1977, p. 77).

Si se atiende a la comparación entre la secuencia completa descrita y el texto literario -más allá de que justo en este pasaje se rompa la original idea mantenida en casi todo el libro de la narración en segunda persona-, cualquier duda sobre la adaptación creativa de la obra fílmica en literaria diez 
años después queda disipada. La traslación creativa no parte solo del espíritu general de la trama, por decirlo así, entre la obra cinematográfica y el libro visible, por ejemplo, si se comparan el discurso final de Yves Montand en el filme y el discurso general del libro-, sino que se traduce de forma explícita en la inspiración expresa en la traducción de lenguajes entre algunos vívidos recuerdos del autor narrados según el caso de una forma mimética, simplemente adaptada a las gramáticas de cada medio, antecediendo en este caso la cinematográfica a la literaria.

Pasando al caso del film Las rutas del sur, dirigido en 1978 por Joseph Losey, con guión original de Semprún, la traslación de los tres niveles entre el Semprún creador, el real y el personaje, vuelve a producirse, en este caso siendo el alter ego, de nuevo encarnado por Yves Montand, Juan Larrea, un pseudónimo utilizado por Semprún en la clandestinidad, y que además da nombre al personaje de su novela - excluida de sus ensayos autobiográficosLa montaña blanca (1986). No obstante, el caso de Las rutas del sur es sensiblemente diferente al de La guerra ha terminado en relación con su obra literaria. Las rutas del sur plantea en su argumento principal la difícil relación entre un escritor y guionista español afrancesado consagrado y su hijo, producto rebelde de mayo del 68, resultando -como La guerra ha terminado- uno de los guiones más personales del autor, hasta el punto de que el propio Losey lo interpretaba como una secuela de aquel filme (Vallet, 2010, p. 287), que refleja de nuevo su vida - y en concreto su complicada relación con su hijo Jaime Semprún- y sus preocupaciones en la pantalla, si bien de la mano de otro prestigioso director. En cualquier caso, el trasfondo político, aun estando presente, es menor que en otros títulos de Semprún. La transfiguración literaria en este caso difiere del modelo anterior aunque puede hallar su eco en la novela Netchaiev ha vuelto (1987), escrita - de nuevo- diez años después de Las rutas del sur. No obstante, la novela, que asume también como trama principal la compleja relación entre un padre, inspector de policía, y su hijo, ex-terrorista revolucionario, tiene un anclaje absoluto en la ficción novelada, no perteneciendo a la serie de ensayos autobiográficos del escritor, que sin duda es la más abundante en su obra literaria. Esta peculiar traslación de un dato fundamental de la biografía del 
autor resulta reveladora de su proceso creador, y revaloriza la importancia de su guión para Las rutas del sur. Precisamente, cuando hablamos de un escritor cuyo principal caudal literario es la memoria $-\mathrm{y}$ en concreto sus vivencias personales-, más o menos alteradas pero narradas de forma expresa a lo largo de más de una decena de libros, no deja de resultar llamativo que en todas esas páginas apenas aflore su intimidad personal y en concreto su experiencia como padre. Resulta entonces expresivo que la fórmula de traslación de su obsesión traumática en ese campo se exprese a través de una metáfora de ficción en una novela pura, Netchaiev ha vuelto, que perfectamente podría integrarse en el género negro. No obstante, el filme Las rutas del sur de nuevo provee al cineasta de un trampolín fílmico para una experiencia vital que luego filtra de forma literaria. De nuevo se produce aquí -como en La guerra ha terminado- un proceso de creación alambicado que transcurre de la realidad al cine, y del cine a la literatura.

El caso de Las dos memorias podría inscribirse igualmente en un proceso creador que transfiere la experiencia filtrada por una plasmación cinematográfica a la literatura, pero el documental - la única realización propia de Semprún - introduce algunas variables que lo diferencian de los casos vistos, partiendo de su naturaleza alejada de la ficción, que no solo interrumpe momentáneamente los tres niveles de presencia de la figura sempruniana ya aludidos, sino que introduce un carácter de ensayo fílmico que actúa en diversas direcciones, como contenedor de citas fílmicas y de anticipos o variaciones sobre diversas obras literarias (Jimeno, 2015: 151158).

El documental propone, a partir de entrevistas con dirigentes políticos históricos e intelectuales, de ambos bandos, pero mayoritariamente del ámbito de la izquierda y en el exilio, una reconstrucción diversa de la memoria sobre la Guerra Civil, la posguerra y el franquismo, que más que alumbrar las dos memorias de los dos frentes, casi podría alumbrar más bien la dualidad entre el enfoque comunista y el anarquista, o plantear excediendo ampliamente la del binomio que propone el título- una mirada poliédrica sobre el conflicto y sobre la historia reciente de España, con la 
indisimulable mirada de un exiliado realista, ejercida por el propio Semprún como narrador.

En este sentido, la relación intertextual establecida por la película es también variada. La estructura temática del film, partiendo del enfoque ideológico del autor, propone básicamente otro anticipo cinematográfico de las tesis defendidas en Autobiografía de Federico Sánchez, introducidas desde un prisma documental y de entrevistas que contiene no solo los testimonios de algunos de los protagonistas del libro escrito tres años más tarde, particularmente los dirigentes comunistas Santiago Carrillo y Simón Sánchez Montero, sino que, de forma metafórica, la intervención testimonial del actor Yves Montand sirve para introducir la conclusión final - presente ya en $L a$ guerra ha terminado- sobre la situación de la España franquista, vista ahora casi en el tiempo de descuento del régimen, para lo cual la cita al filme resulta expresa, utilizándose parte de una secuencia en la que el diálogo resume el pensamiento del autor. Es decir, si bien a modo de un ensayo audiovisual, Semprún precede su reflexión literaria componiendo un texto que integra también citas a previos trabajos cinematográficos. Así mismo, aunque el carácter intimista o emocional del film es menor en comparación con el peso del discurso ideológico general, los momentos en que el autor voz en off mediante- recuerda el comienzo de su exilio familiar, descritos a partir de imágenes en blanco y negro de los exiliados españoles, comparadas con imágenes en color de los campings que en 1974 se encuentran donde en su día estuvieron los campos de refugiados, resultan también un precedente cinematográfico adaptado después recurrentemente en sus obras literarias de signo autobiográfico, particularmente en una de ellas: Adiós, luz de veranos (1998), acaso la obra más personal del autor, en la que recupera poéticamente por escrito el espíritu y la letra de la secuencia de apertura de Las dos memorias:

Mis primeros recuerdos de aquellos primeros momentos de exilio son vagos, confusos. Estaban los veraneantes que nos miraban con curiosidad más bien hostil (...). Nuestra llegada les recordaba la proximidad de la guerra, los peligros de la historia, del mundo real (Semprún, 2011, p. 168). 


\section{De la literatura (de otros) al cine pasando por la vida}

Dentro de este epígrafe se da cuenta de los casos en que Jorge Semprún adaptó al cine como guionista novelas de otros escritores, haciendo especial hincapié, por su trascendencia cinematográfica, pero también por la incidencia de la personalidad (y de la experiencia) del autor, en los filmes en los que trabajó con el cineasta Costa-Gavras, aunque el análisis se amplíe también a otros títulos. En este caso, el planteamiento, dentro del ejercicio habitual de adaptar un texto literario ya existente al cine, tiene una originalidad particular, ya que Semprún -que escribe el guión solo o colaborando con el director-, aun mostrándose fiel no solo al espíritu sino también al argumento o estructura de la obra que adapta, introduce variaciones o plantea paralelismos que de nuevo establecen relaciones multidireccionales entre su experiencia vital y su propia obra literaria.

Entre 1968 y 1975, y más allá de proyectos frustrados en ese periodo o con posterioridad, el cineasta Costa-Gavras y Jorge Semprún colaboran en tres películas, estableciendo una especie de tándem cinematográfico, que a partir del éxito internacional de su primer filme juntos $-Z$ (1969) -, modelará una nueva vía concreta de cine político, muy imitada posteriormente, a medio camino entre un cine de género atractivo comercialmente y un cine de denuncia y reflexión.

El caso de $Z$, filme muy célebre que narra el asesinato de un diputado griego (encarnado por Montand) por un complot político y militar que desemboca en un golpe de Estado, inaugura la primera aproximación de Semprún a un material literario ajeno frente al planteamiento expresamente autobiográfico de La guerra ha terminado. El filme, que en su momento trascendió incluso su carácter cinematográfico convirtiéndose en un símbolo político - por su abierta denuncia de la dictadura griega coetánea-, parte de una novela homónima de Vassilis Vassilikos, publicada en 1966, y que a su vez se basaba en hechos acontecidos realmente.

En este caso, el guión construido por Semprún y Costa-Gavras con diálogos de Semprún, plantea un modelo fiel a la estructura de la novela original, planteada como un relato policiaco-político con un intermedio que actúa 
como monólogo interior del personaje de la viuda del protagonista, y una segunda parte que modifica la perspectiva situando el centro de la trama en la investigación judicial del caso.

En cuanto a la traslación de su universo temático, biográfico y literario, filtrado entre los meandros del texto original de Vassilikos y de la historia del filme, $Z$ presenta una intensidad menor y más disimulada que la que contendrá, por ejemplo, el siguiente filme en que ambos colaboran, La confesión (1971). En este sentido, en el guión de $Z$ adaptado de la novela de Vassilikos, la marca autoral de Semprún aparece en tres niveles.

En el primer nivel, desde un punto de vista temático en líneas generales, más allá del lógico interés de Costa-Gavras en plantear una historia que hable del caso griego, Semprún establece una cierta analogía entre la historia política griega y la española, como él mismo explica:

Por mi parte, había un cierto paralelismo entre la historia de Grecia y la de España, dos países que habían sufrido una guerra civil, en los que había existido una guerrilla y habían sido víctimas de una determinada estrategia angloamericana. (Riambau, 2007, p. 52).

Pero además, la propia idea expresa de que el filme no sitúe explícitamente (aunque sí de modo evidente) la acción en ningún país determinado -en el filme nunca se cita Grecia ni ningún nombre que se asocie, aunque hay múltiples evidencias implícitas-, responde - entre otros motivos- a la voluntad de los autores de querer generalizar su discurso ideológico en un planteamiento global, que pudiese incluir evidentemente el caso español.

No obstante, situándonos en el segundo nivel en el que se hace visible la huella autoral sempruniana, la aportación más perceptible se encuentra asociada a su estilo formal, y a sus implicaciones en cuanto a la representación de la memoria. El escritor traslada su particular fórmula literaria de la ruptura espacio-temporal del relato al guión, que resulta completamente opuesta a la habitual inclusión de flashbacks, y que actúa más bien como una conexión no causal de recuerdos que representan imágenes mentales, fugaces intromisiones de la memoria que rompen la línea principal o fugas narrativas adelante o atrás en el tiempo, como el 
mismo Semprún señala: "Empiezo una historia y después, de repente, paso a algo completamente distinto. (...) A ciertas personas les parece irritante. A otras les gusta" (Augstein, 2010, p. 269). Este recurso es una técnica permanente y habitual en su obra literaria, que había introducido ya cinematográficamente en La guerra ha terminado (Riambau, 2007, p. 5657), y que aunque con menor profusión aparece también en $Z$, como idea introducida al margen de la novela de base, e incluso de la trama principal. Por ejemplo, acudiendo al momento del filme en que más claramente aparece integrada esta fórmula, en un aparte completamente ajeno a la trama, al comienzo, el personaje del diputado (Yves Montand) se queda mirando el maniquí de un escaparate. Con un corte simple de montaje, en la secuencia siguiente se le muestra con su amante (esta provista de una peluca) en una consulta, siendo descubierto por su esposa (Irene Papas). En el filme, la introducción de este fragmento actúa como una interrupción fugaz y extraña, que glosa emocionalmente al personaje recurriendo a una estratagema casi proustiana y que refuerza su distanciamiento (e incluso un cierto desencanto) con respecto a la imagen totémica que tiene ante sus compañeros de partido y la población en general. En la novela de Vassilikos, aún existiendo un breve pasaje que sirve como base de la escena, el planteamiento es muy diferente:

¿Qué era ese pueblo que había llegado a vender su pelo y sus ojos? Su pelo para hacer pelucas para mamarrachos. Como esa americana a la que había conocido unos meses antes, que quería hacerse un aborto. Al quitarse la peluca rubia, había descubierto un pelo castaño, corto como el de un adolescente. Entonces tomó la peluca y empezó a soñar; ¿de qué mujer procedían esos cabellos? (Vassilikos, 1977, p. 68).

En el libro de Vassilikos la referencia a la existencia de una amante del personaje no existe como tal, y la situación descontextualizada resulta una anotación mínima que apenas ocupa dos líneas, y que viene introducida por una idea diferente y metafórica sobre el sojuzgamiento del pueblo griego, desvinculado de las relaciones extraconyugales del personaje y del efecto emocional introducido por Semprún. 
El tercer nivel, el de la construcción de un otro yo ficticio es más endeble en el caso de $Z$, pero, como apunta particularmente Bucarelli (Bucarelli, 2011, p. 56), puede rastrearse en uno de los personajes secundarios del filme, que cobra una importancia mayor con respecto a la novela, y al que además se bautiza como Manuel -un nombre español, que coincide con el del protagonista de La esperanza de André Malraux, y que en homenaje a ese hecho fue utilizado por Semprún en la clandestinidad, siendo además recurrente en sus obras literarias-. Este personaje (encarnado por Charles Denner) es uno de los miembros del "coro griego" que acompaña al malogrado diputado y en su escasa semblanza comparte múltiples rasgos con el propio Semprún militante, como el ser el responsable de las organizaciones políticas universitarias -como hacía Semprún en España durante los años cincuenta-, tiene raíces judías, como el propio Semprún, y resulta el único del grupo de partidarios del diputado que, en una tímida alusión a la experiencia biográfica de Semprún con el Partido Comunista Español, mantiene una línea separada con respecto a la estrategia política del comité pacifista (Bucarelli, 2011, p. 56).

En relación precisamente con esta particular idea de alter-ego -y también de paso al detalle del origen judío que permite al autor introducir una cuestión esencial de su imaginario ideológico-, el siguiente filme dirigido por Gavras con guión de Semprún (en este caso en solitario), La confesión, plantea intensamente la transfiguración del escritor español en el personaje (de nuevo encarnado por Yves Montand), aunque la historia (real) que se narre sea la de un represaliado checo, Artur London, y la base literaria sean sus propias y prolijas memorias La confesión. En el engranaje del proceso de Praga, publicadas originalmente en 1968.

El caso de La confesión es un ejemplo peculiarísimo de la relación especular entre el Semprún narrador y el Semprún personaje, pero utilizando en este caso una obra de base ajena, escrita a su vez por su protagonista, dirigente del Partido Comunista Checo caído en desgracia durante las purgas estalinistas de los años cincuenta. El material, que le sirve a Costa-Gavras para efectuar una dura denuncia del estalinismo, en clave con el modelo 
cinematográfico que parte de $Z$, y si bien con una densidad política mayor, se convierte en la metáfora del propio problema político -la disidencia, sanción y expulsión del Partido Comunista- de Jorge Semprún, en un reforzamiento de los planteamientos que aparecerán en la Autobiografía de Federico Sánchez, entre otros escritos.

Si bien La confesión narra - con alta fidelidad al libro autobiográfico de London- el proceloso proceso de detención, torturas y encierro al que fue sometido el dirigente checo, rehabilitado después de la desestalinización, el paralelismo entre la vivencia real de London y la de Semprún marca la perfecta posibilidad de la identificación entre la representación de sus proyecciones en la ficción. El filme se convierte así en una suerte de metáfora de la evolución ideológica del autor en relación con el PCE, e incluso más allá, en su libro póstumo Ejercicios de supervivencia (2011), de las propias torturas sufridas -más allá de metáforas- durante su detención por la Gestapo. En definitiva, el paralelismo de ambas trayectorias pasa en los dos casos por la Guerra Civil Española, en la que London combatió como miembro de las Brigadas Internacionales mientras Semprún se exiliaba, la militancia antinazi, su experiencia en un campo de concentración (Mauthausen en el caso de London y Buchenwald en el de Semprún), su ascendencia judía, o el planteamiento en torno al comunismo y a los partidos comunistas, desde la militancia hasta la disidencia, y la reflexión ideológica en torno a la distancia entre praxis política e ideología original. Incluso el personaje encarnado por Montand -trasunto cinematográfico casi permanente de Semprún- se llama en el filme Gérard, pseudónimo clandestino tanto de London como de Semprún durante su participación como resistente antinazi (Semprún, 1986, pp. 89-90), elemento que él mismo narra detalladamente por escrito en su biografía personal sobre Montand (Semprún, 1983, pp. 152-154) y que había integrado también en su libro de 1980 Aquel domingo (Semprún, 1986, pp. 157-158), en el que narra su encierro en Buchenwald y en el que cuenta cómo coincidió en el campo con otros dirigentes checos y eslovacos también purgados junto con London. En este sentido, más allá de otras marcas autorales de Semprún presentes en el relato fílmico -como la estructura temporal fragmentada y la introducción de 
pequeños flashes emocionales, ya presente en $Z$ y en La guerra ha terminado-, sin constituir un film autobiográfico antecedente de algunas de sus obras literarias, La confesión es -junto con La guerra ha terminado y Las rutas del sur-, el otro gran filme personal del autor, que funciona en dos estadios: como fiel adaptación de las memorias de London, y como vuelta de tuerca sobre los ejes creativos, literarios y biográficos del autor.

El caso de la tercera y última colaboración entre Gavras como director y Semprún como guionista, Sección especial (1975), se situaría a medio camino entre el caso de $Z$ y el de La confesión, aunque el proceso creativo se encuentre más cercano al primer filme. En este caso, los autores adaptan un ensayo histórico de Hervé Villeré, L'affaire de la Section spéciale, publicado en 1973, que narra de forma documentada y detallada el proceso-farsa llevado a cabo por un tribunal francés durante la ocupación nazi para condenar a muerte a seis presos políticos aleatorios, como represalia por un atentado de la Resistencia francesa. La primera diferencia con respecto a las otras dos películas es que el material de base no es ni una novela ni una biografía, sino un libro histórico, con abundante información de archivo, que adquiere en ocasiones los modos de un informe crítico. En este sentido, el film es una crónica mayoritariamente distanciada que expone los hechos con la idea de producir un determinado efecto crítico en el público. No obstante, igualmente integran como en el caso de $Z$ un nivel histórico asociado a Semprún -el contexto vivido por él de la Resistencia y la ocupación- y un planteamiento estilístico que recupera (si bien brevemente) la idea de los flashbacks emocionales breves a la hora de presentar a los reos juzgados por el tribunal. No obstante, en este caso la transferencia entre el Semprún narrador y el literario, filtrada por una historia ajena, se produce en la primera parte del filme, cuando se narran los atentados de la Resistencia y como en La confesión-, Semprún plantea una mixtificación entre el relato adaptado del informe y su propia experiencia, expresada en el filme y más adelante en su literatura.

En esta parte de la película - planteada como un prólogo-, la narración se hace eco de la formación de comandos de jóvenes resistentes, organizados 
por militantes comunistas, mostrando en una de las secuencias principales una manifestación por el centro de París que termina con una gran redada, y que desemboca en la muerte de un joven atrapado por los soldados alemanes, que a su vez provocará como represalia la ejecución de un oficial nazi en el metro de París. Muchos años después del filme, Semprún narra en diversos libros, principalmente La escritura o la vida (1994), Adiós, luz de veranos (1998) y Viviré con su nombre, morirá con el mío (2001) su experiencia en la Resistencia francesa:

Estuvimos juntos en la manifestación del 11 de noviembre de 1940 en los Campos Elíseos; juntos también conseguimos escapar de las redadas de la policía parisiense y del batallón de la Wehrmacht que el Estado Mayor nazi envió para desalojarnos del barrio. (Semprún, 2011, p. 126).

Más allá de la concesión de verosimilitud exacta que puede plantearse entre la realidad y lo que Semprún plasma en sus ensayos autobiográficos, o autobiografías ficcionadas, el interés de la relación entre este pasaje y el filme vuelve a marcar la conexión entre su proceso creativo como guionistaadaptador de un material ajeno y la filtración de su propia realidad luego expresada en obras literarias posteriores.

Tanto desde el punto de vista de la trascendencia cinematográfica como desde la óptica de la plasmación de la personalidad de su artífice Semprún, su filmografía fundamental está constituida por el binomio que compondrían, por un lado, sus tres colaboraciones con Costa-Gavras, y por otro, el díptico autobiográfico formado por La guerra ha terminado y Las rutas del sur, a los que podría añadirse el documental Las dos memorias. No obstante, y aunque no es demasiado amplia, la filmografía como guionista de Jorge Semprún incluye otros títulos en los que puede hallarse también el mismo proceso creativo de adaptación de materiales diversos conectados con el propio mundo real y literario de Semprún.

En este sentido, y dejando al margen su guión, con Ben Barzman y Basilio Franchina para El atentado (L'attentat, Yves Boisset, 1972), que se inscribe en la línea del cine político de emulación de $Z$ tras su éxito, hay dos filmes que de algún modo plantean otra particular relación con el mundo literario 
sempruniano. El primero es Stavisky (id., Alain Resnais, 1974). La idea del filme parte de la narración del caso real de un estafador judío bastante célebre en el periodo de entreguerras (encarnado por Jean-Paul Belmondo) que se codea con la alta burguesía francesa y que incluso participa en la financiación de actividades políticas fascistas. Más allá del interés temático del contexto histórico-político de ese periodo (que permite a Semprún introducir colateralmente el tema de la Guerra Civil Española), la originalidad de la conexión con su universo parte de una subtrama de la película que narra el exilio de Trotsky a Francia antes de su marcha definitiva a México donde sería asesinado por el español Ramón Mercader. En 1969, Semprún había escrito su segunda novela La segunda muerte de Ramón Mercader que, aunque planteaba -sin el recurso directo al ensayo autobiográfico- una trama de espionaje contemporánea que incluía un juego en torno a la repetición del nombre del asesino de Trotsky, integraba en su engranaje de saltos temporales otra subtrama sobre el exilio mexicano del exlíder soviético. En este sentido, la relación entre la novela de 1969 y el filme de 1974 es indirecta pero complementaria. Hasta el punto de que Semprún teje un microcosmos histórico relacionado en el sentido de que dos subtramas de relatos diferentes - centradas en el mismo episodio histórico de la caída en desgracia de Trotsky, elemento sin duda análogo para Semprún con su propia caída en desgracia en el PCE- son recuperadas alternativamente de modo simultáneo en un relato de ficción literario, $L a$ segunda muerte de Ramón Mercader, y en uno cinematográfico, Stavisky.

En el mismo contexto histórico en el que se desarrolla Stavisky -los años treinta, particularmente el verano de 1936, pero en este caso en Grecia- tiene lugar la historia que se relata en otro guión de Semprún susceptible de ligarse a su universo biográfico y literario; se trata del guión del filme Una mujer en la ventana (Une femme à sa fenêtre, Pierre Granier-Deferre, 1976). En este caso, el guión es una adaptación de la novela homónima de Pierre Drieu La Rochelle escrita en 1929. La primera decisión personal de Semprún es, aun manteniendo la ambientación en Grecia, trasladar temporalmente la acción a 1936, haciendo coincidir la acción con el punto de ebullición de los fascismos europeos, y en concreto con la instauración de la dictadura de Metaxas en el 
país heleno y con el estallido de la guerra en España. Es decir, Semprún recupera la analogía entre Grecia y España que planteaba abstractamente en $Z$-en este caso expresa, llegándose a ver un noticiero en un cine que da cuenta del golpe militar de Franco-. El filme narra la historia de una bella aristócrata (Romy Schneider), esposa de un diplomático italiano (Umberto Orsini), con el que mantiene una relación abierta, que se convierte en protectora de un líder comunista (Victor Lanoux), perseguido por la policía política. Semprún -en línea con sus habituales estructuras literarias- plantea el relato en varios tiempos, cronológicamente desordenados, e integra sus obsesiones temáticas e ideológicas, incluyendo los procesos de Stalin contra sus oponentes. No obstante, el punto clave de la narración es de nuevo la transferencia de su personalidad militante a un alter ego, presente y protagonista de la novela de Drieu La Rochelle, pero dibujado cinematográficamente con los atributos de un Federico Sánchez previo al franquismo. El personaje encarnado por Victor Lanoux que ostenta su nombre real y el clandestino es la rima exacta de la personalidad que el Semprún escritor otorga al Semprún personaje en sus ensayos autobiográficos: un líder comunista clandestino perseguido por la policía política fascista, representada por un grotesco jefe -trasunto a su vez del comisario Conesa, perseguidor de Semprún durante el régimen, retratado con idénticos mimbres en diversos escritos de Semprún, pero particularmente en Federico Sánchez se despide de ustedes (1993)-, que ostenta un equilibrio inmejorable entre la acción política y la capacidad de moverse en la clandestinidad, con su carácter de elemento crítico del partido desencantado intelectualmente y que al tiempo se relaciona con la alta burguesía revelando su capacidad de seducción sexual. El prototipo planteado por Semprún en Una mujer en la ventana es análogo tanto a los protagonistas de las ficciones literarias semprunianas (cargados precisamente de esa habilidad seductora) y, en definitiva, trasuntos fabulados de su propia personalidad, como de los ensayos autobiográficos en que la relación entre el Semprún escritor y el personaje es más directa en su doble identidad. 


\section{Conclusiones}

La idea que se obtiene al tomar los principales trabajos cinematográficos de Jorge Semprún, como guionista y director, y equipararlo a su obra literaria teniendo en cuenta sus diversos orígenes, es la de la existencia de una red de relaciones intertextuales que reflejan en definitiva la traumática experiencia biográfica de la primera parte de su vida, que podría resumirse en cuatro grandes etapas: exilio, resistencia antinazi, confinamiento en Buchenwald y etapa clandestina antifranquista, rubricadas por el episodio de la expulsión del Partido Comunista de España en 1964.

Toda la creación artística posterior (literaria y cinematográfica) refleja con distintos formatos esa experiencia biográfica, entretejida a partir del uso de temas, episodios, reflexiones y personajes de forma repetida, transmutada y modificada entre la realidad y la ficción, y también entre el cine y la literatura.

En este sentido, si su obra literaria puede ser dividida, de forma puramente analítica, puesto que la disociación absoluta provocaría errores de matiz, entre las novelas puras y los ensayos autobiográficos o biografías noveladas, en realidad, su trabajo cinematográfico contiene un elemento de trasposición de ese binomio de géneros. Es decir, Semprún escribe novelas con tramas de ficción en las que introduce elementos biográficos, alter-egos románticos y hechos realmente acontecidos de los que ha sido testigo privilegiado. En paralelo, crea obras literarias de signo realista y autobiográfico en las que, como ha demostrado Soledad Fox en su biografía (Fox, 2016, p. 51), aún narrando hechos de su experiencia introduce licencias poéticas conscientes que aportan un componente de fabulación a las vivencias relatadas. En este sentido, la filmografía como guionista de Semprún parte de una división, que aún siendo compleja de disociar, introduce la misma circunstancia. En sus películas podemos encontrar, como en sus novelas de ficción, historias aparentemente distanciadas que parten de novelas o textos de terceros (sus filmes con Costa-Gavras, Stavisky y Una mujer en la ventana), pero que acaban conteniendo elementos biográficos y trasuntos ficticios, mezclados con el relato original habitualmente adaptado de forma fiel, aunque sus 
fisuras o identidades permitan la analogía. Del mismo modo, como en sus ensayos autobiográficos literarios (Autobiografía de Federico Sánchez, La escritura o la vida, Adiós, luz de veranos, entre otros), encontramos filmes (La guerra ha terminado, Las rutas del sur), que, aun estando dirigidos por otros realizadores, de imponente personalidad cinematográfica además, resultan la correlación exacta de sus biografías fabuladas, contando sus vivencias con la licencia creativa de aportar elementos ficticios que los completen.

En este sentido, la conclusión en torno a la obra cinematográfica de Semprún es, en primer lugar, que se articula creativamente de forma mimética a su creación literaria en cuanto a la forma y la estructura, adaptando esta al lenguaje de cada medio, y utilizando el género o la temática como contenedor expreso o implícito de su universo. Pero más allá, al comparar ambas creaciones, sus relaciones intertextuales y conexiones, variaciones e influencias, se comprende que toda su obra cinematográfica forma parte de un mismo mundo de creación, indisociable del literario, que se concibe como una cosmogonía sempruniana formada a partir de retales y en constante mutación formal, cosida por el hilo de la memoria del narrador.

\section{Referencias bibliográficas:}

Augstein, F. (2010). Lealtad y traición. Jorge Semprún y su siglo. Barcelona: Tusquets.

Céspedes, J. (2011). Cinéma et engagement. Jorge Semprun scénariste. Condé-sur-Noireau: CinémAction-Éditions Charles Corlet.

Fox Maura, S. (2016). Ida y vuelta. La vida de Jorge Semprún. Barcelona: Debate.

Jimeno Aranda, R. (2015). Jorge Semprún, la memoria de un cineasta. Experiencia vital, literatura y principios ideológicos en Les deux mémoires (1974). En Castán, J. (Ed.). Estudios de historia y estética del cine. $50^{\circ}$ aniversario de la Cátedra de Cine de la Universidad de Valladolid. (151-158). Valladolid: Universidad de Valladolid, Cátedra de cine de la Universidad de Valladolid.

London, A. (2000). La confesión. En el engranaje del proceso de Praga. Vitoria-Gasteiz: Ikusager Ediciones. 
Nieto, F. (2014). La aventura comunista de Jorge Semprún. Exilio, clandestinidad y ruptura. Barcelona: Tusquets.

Resnais, A. (1966). La guerre est finie. Francia: Europa-Film / Sofracima.

Riambau, E. (2007). De traidores y héroes. El cine de Costa-Gavras. Guadalajara (México): Festival Internacional de Cine de Guadalajara y Universidad de Guadalajara.

Semprún, J. (1977). Autobiografía de Federico Sánchez. Barcelona: Planeta.

Semprún, J. (1983). Montand, la vida continúa. Barcelona: Planeta.

Semprún, J. (1986). Aquel domingo. Barcelona: Seix Barral.

Semprún, J. (1994). La escritura o la vida. Barcelona: Tusquets.

Semprún, J. (1998). Adiós, luz de veranos. Barcelona: Tusquets.

Semprún, J. (2011). Viviré con su nombre, morirá con el mío. Barcelona: Tusquets.

Semprún, J. (2016). Ejercicios de supervivencia. Barcelona: Tusquets.

Vallet, J. (2010). Joseph Losey. Madrid: Cátedra.

Cómo citar: Jimeno Aranda, R. (2017). El cine de Jorge Semprún. La transferencia entre guiones cinematográficos, literatura y biografía. Fotocinema. Revista científica de cine y fotografía, $\mathrm{n}^{\mathrm{0}} 14$, pp. 59-81. Disponible: http://www.revistafotocinema.com/ 